\title{
Disentangling the Effects of Fair Trade on the Quality of Malian Cotton
}

\author{
Gaëlle Balineau
}

GaËlle Balineau is an Economist. She defended her PhD thesis at Cerdi (Centre for Studies and Reserach on International Development, ClermontFerrand, France) in 2010, titled "Is Fair Trade a development tool?". The impact evaluation of the "Fairtrade cotton project" in Mali has been an important part of her research. She is currently a Consultant for various organizations (the World Bank and the FERDI, in particular). Her research interests include Fair Trade, Aid for Trade, and Trade and Climate Change.

\section{Abstract}

The increasing importance of premium segments and the proliferation of private labels and certification schemes raise skepticism about the ability of Fair Trade (FT) to help smallholders compete in high value-added markets. Based on a panel dataset collected in Mali in 2008, this paper contributes to the debate by estimating the impact of FT on the quality of Malian cotton. Controlling for selection bias and for a potential increase in quality prior to FT certification, results show a significant impact of FT on the quality of cotton produced by both certified and geographically close non-certified growers via spillover effects. 


\section{Acknowledgments}

Field research for this study has been funded with a contribution from the French Ministry of Foreign Affairs, the Regional Council of Auvergne (France), and the Centre for Studies and Research on International Development (CERDI, Clermont-Ferrand, France). I would like to thank the Compagnie Malienne pour le Développement des Textiles (CMDT, Mali) for outstanding assistance in conducting the surveys, as well as the survey team. I gratefully acknowledge the collaboration of surveyed cooperatives and farmers of the Kita region. I am indebted to Catherine Araujo-Bonjean, Jean-Louis Arcand, Pascal Babin, Delphine Babin-Pelliard, Alain de Janvry, François Giraudy, and Elisabeth Sadoulet for their help in designing the impact evaluation. I would also like to thank Jenny C. Aker, Tanguy Bernard, Olivier Cadot, Jaime de Melo, CERDI seminar and 2009 AfrEA-NONIE-3IE International Conference on Impact Evaluation participants for comments on earlier versions of this paper. Finally, I thank FERDI (Clermont-Ferrand, France) for financial support to publication. All remaining errors are mine.

\section{Introduction}

Over the last decade, skepticism about the ability of Fair Trade (FT) to generate sustainable benefits to producers in developing countries has increased hand in hand with its notoriety. On the empirical side, as underlined by Ruben and Forth (2011), recent impact evaluations that take into account the selection bias inherent to the participation in FT markets tend to relativize previous results of many enthusiastic case studies. First, they challenge the ability of FT to deliver on its core principle - guarantee higher prices and incomes to producers than in the conventional sector. Indeed, net of inflation (Bacon, 2010; Jaffee, 2008) or of FT certification costs (Weber, 2011), FT prices are often lower than expected. And even when they are shown to be higher than those obtained on conventional markets (Arnould, Plastina \& Ball, 2009; Bacon, 2005) or to be more satisfactory to producers (Becchetti \& Costantino, 2008), their impact on net income could be small due to higher production costs (mainly due the intensification of labor efforts - see for example Barham, Callenes, Gitter, Lewis \& Weber, 2011; Beuchelt \& Zeller, 2011; Valkila, 2009). As regards the second pillar of $\mathrm{FT}$ - the technical assistance provided to producers' organizations (POs) in order to strengthen their capacities, some impact evaluations confirm the positive effect of FT found in previous case studies on the POs' governance and management (Balineau, 2011; Ruben \& Forth, 2011), and on their bargaining power (Becchetti, Costantino, \& Portale, 2008; Ronchi, 2006). However, it remains very difficult to ascertain if these improvements would subsist in the absence of FT standards that POs have to comply with to be certified, and if they have an impact on the ability of producers to get higher prices and incomes on non-FT markets which is crucial given that FT is still confined to a niche market.

Since the efficiency of FT schemes and their sustainability are also questioned from a theoretical point of view, the literature actually suggests that the cost-benefit analysis of FT does not

\footnotetext{
1. Whether FT is a new form of product-differentiation or it introduces a market distortion via higher prices for non-differentiated products remains the cornerstone of the theoretical debate on FT. According to de Janvry, McIntosh and Sadoulet (2010), for example, FT explicitly delivers rents to producers as it "is not based on altering the process through which a product is produced, but rather on improving the price that producers receive" (p.1). Leclair (2002, 2008), and Yanchus and de Vanssay (2003), share this point of view. Based on philanthropic consumers and not on a real differentiation (Mendoza \& Bastiaensen, 2003), FT is thus likely to prolong the dependence of producers on products "which have poor prospects in the long run" (Leclair, 2002, p.949). Indeed, while products such
} 
argue in its favor. Many authors therefore suggest "restructuring FT to create greater producer benefits" (de Janvry, McIntosh, \& Sadoulet, 2010, p.21). Some argue that FT should, as its founding principles state, be re-designed as a support to the development of commercial capacities. For example, Mendoza and Bastiaensen (2003) think that the networks and capacities built by the different FT organizations could help small-scale farmers get larger shares of the high-value export markets that FT tries to compete in ("specialty coffees" for example, see Kaplinsky, 2006). However, until now, we do not know if, and how, FT could support producers in developing countries in keeping up with high quality requirements and gaining market shares on high value-added segments that already suffer from saturation (World Bank, 2007).

This paper gives evidence that FT contributes to raising the quality of cotton production in Mali where the implementation of FT was to improve and promote the quality of, and hence the demand for, Malian cotton. Its contributions revolve around the identification strategy that addresses three issues that could prevent us from distinguishing the effects attributable to FT from those due to other factors (cooperatives' inherent characteristics or time effects for example). First, the staggered entry of Malian cooperatives in FT is exploited to set up time and fixed-effects regressions, and thus to tackle the selection bias problem due to the non-random selection of participants. Second, the empirical strategy is also designed to estimate spillover effects, considered as an explicit objective of the FT cotton project and which, if not taken into account, would lead to underestimate the impact of FT on certified cooperatives. Third, the possibility that FT cooperatives might be selected based on previous quality performance is dealt with in detail. This paper therefore adds to the counterfactual impact evaluations of FT which are still very scarce, especially for products other than coffee and regions other than Latin America.

Results show that FT increases the share of top quality cotton in certified cooperatives by 7 percentage points (pp), and that it has large spillover effects as the impact of FT on neighboring non-FT cooperatives is a $5 \mathrm{pp}$ rise in the top quality cotton. In other words, FT accounts for more than half of the quality improvement observed in the FT region (where the proportion of top quality cotton increased from 3 to $16 \%$ over the period studied). Having tested for the possibility of other explanatory factors, I conclude that one can be confident that the impact is accounted for by the enhanced producers' incentives implied by the FT contract. Indeed, in addition to the price differentiation according to quality, the FT contract introduces clearer quality criteria, a more credible grading of cotton, as well as collective cooperation incentives. ${ }^{2}$

The remainder of the paper proceeds as follows: Section 2 provides an overview of the cotton sector in Mali and details the objectives of the FT cotton project. Section 3 presents the data and the identification strategy. Section 4 contains the empirical results. Section 5 draws the implications of the results and concludes.

\footnotetext{
as coffee are already characterized by oversupply, the FT price floor deters diversification and removes the incentive for growers to upgrade production or invest in market knowledge (Zehner, 2002). Moreover, although this conclusion may depend upon restrictive hypotheses (see Hayes, 2008); the FT price could increase overproduction and deteriorate the condition of non-FT producers. This argument is frequently put forward by multinational firms to defend their own quality-labels against FT (for example, Nestlé argues that its "specialty coffees" offer better perspectives than FT, see Fridell, Hudson \& Hudson, 2008). On the contrary, Balineau and Dufeu (2010), Becchetti and Rosati (2007), and Kaplinsky (2006), consider FT products as differentiated because they are produced and exchanged according to specific terms and conditions. However, inefficiency may still arise from higher costs of processing and marketing, due to small volumes traded and higher associated costs (certification, membership fees, advertising and campaigning, see World Bank, 2007).

2. Bolwig, Gibbon and Jones (2009) find similar results with organic-coffee contract farming in Uganda.
} 


\section{Fair trade cotton in Mali: Context and objectives}

\section{(a) Overview of the cotton sector in Mali}

Cotton production in Mali first increased under the impulse of the French state-owned Companie Française pour le Développement des Fibres Textiles (CFDT) created in 1949. The Compagnie Malienne pour le Développement des Texiles (CMDT) has continued to support the development of cotton production since $1974 .^{3}$ CMDT controls the cotton supply chain. At the production level, it supplies POs (mainly cooperatives) with inputs (seeds, fertilizers, pesticides) on credit, facilitates their access to equipment, and provides them with technical assistance to improve yields and cotton quality. CMDT purchases farmers' entire production at a fixed national price, which producers know before planting. Input credits provided are reimbursed by POs through deduction from the purchase price of cotton. Downstream, CMDT collects seed cotton at the village level, transports and gins it in its factories, and finally grades and exports cotton lint.

Since 1974, this vertically-integrated structure has been associated with higher cotton production in Mali. Over the past thirty years, areas planted and volumes produced have both multiplied by five, the latter growing from 100,000 tons in 1975 to more than 500,000 tons in 2005. The crop represents 50\% to 60\% of the country's export revenues, fosters economic growth and contributes to rural development, as three million people are estimated to rely directly or indirectly on cotton for their livelihoods (Wodon, Briand, Labaste, Nouvé, \& Sangho, 2006).

However, after thirty years of expansion, the profitability of the Malian cotton sector is seriously threatened by two main factors. First, while real world cotton prices divided by two between 1980-81 and 2004-05, ${ }^{4}$ Malian cotton yields have stagnated, reducing the overall profitability of the crop (ibid.). Second, an unfavorable euro-dollar exchange rate exacerbates the difficulties faced by the cotton sector, reducing the CMDT's turnover in local currency, and hence its capacity to pay producers. The combination of these factors has forced CMDT to significantly cut prices paid to producers, thereby undermining the profitability of the crop for many farmers. ${ }^{5}$ According to Poulton et al. (2004), there are only two ways to make the cotton sector profitable again: Increasing yields and/or promoting the quality of the Malian fiber to foster demand and get better prices on world markets. The problem is that costly programs would be needed to achieve these goals, and CMDT cannot bear an additional financial burden. In this context, FT appeared as an obvious solution to improve quickly farmers' livelihoods. However, in order to increase its benefits, the different stakeholders (CMDT and its then French shareholder DAGRIS, ${ }^{6}$ as well as donors) integrated the FT cotton project in the cotton sector development strategy as a key component of the quality policy. The next subsection details this strategy.

\footnotetext{
3. Until recently, CMDT was owned by the Malian government (60\%) and the CFDT (40\%), restructured in 2001 to become DAGRIS (Développement des Agro-Industries du Sud). DAGRIS has been recently privatized and the new company (Géocoton) now holds less than $5 \%$ of CMDT.

4. Although the decline in world cotton prices has been mostly attributed to the effect of government subsidies given to cotton growers in the United States, the European Union, and China (Wodon et al., 2006), there are other forces at work: On the supply side many technological improvements (improved seed varieties for example) have reduced production costs. On the demand side, per capita consumption is stagnant and suffers competition from synthetic products. For more details and references on the decline in world cotton prices, see Tschirley, Poulton, \& Labaste (2009).

5. At the national level, the sustainability of cotton production is also uncertain as the deficit of the CMDT reached 1.8 percent of Mali's GDP in 2005 (91 million USD, see Tschirley et al., 2009, p.67)

6. See endnote 3
} 


\section{(b) Using Fair Trade to promote the quality of Malian fiber}

\section{(i) The deterioration of the Malian cotton quality}

Quality is of utmost importance for survival in the cotton market as it contributes to determine premiums and discounts above or below the international benchmark given by the Cotlook $\mathrm{A}$ Index ${ }^{7}$ (Larsen, 2003). Besides, in the context of an increasingly strong competition between growing countries, good quality lint can find ready buyers even in a situation of oversupply, whereas spinners would refuse low-quality fiber (Poulton et al., 2004). Spinners particularly refuse to purchase sticky and contaminated cotton. Indeed, stickiness (which is mainly due to insect honeydew deposits on the lint) causes costly disruption in yarn-spinning processes and may damage the processing equipment. Contamination by leaves, branches, plastic waste, sand, dust, and so forth is even more feared because damages caused by foreign matter "becomes visible only after dyeing, when it is too late to remedy" (Larsen, 2003, p.14).

Despite the fact that Malian cotton is hand-picked, and hence should contain less foreign matter than machine-stripped cotton, contamination of the Malian fiber has worsened as production increased, because of less care during picking. Polypropylene traces from harvesting sacks and organic matter are the main source of contamination. In 2003, the International Textile Manufacturers Federation (ITMF) biennial survey of spinners' perceptions ranked Mali the 2oth "most contaminated" source of cotton out of 75 descriptions tested (ITMF, 2008, p.116). This tarnishing reputation has led Mali to lose some clients, especially among Asian spinners (Bassett, 2010). The problem is that once the image of a national crop has suffered it becomes very difficult for it to recover its reputation and re-gain a specific market segment (Larsen, 2003).

\section{(ii) The CMDT's quality policy}

In an effort to improve both the quality and the reputation of Malian cotton, CMDT launched a quality policy in 2003. Since most sources of contamination and stickiness can be solved at the farm level (Larsen, 2003), extension agents now provide growers with intensive quality management advice; and a premium is annually awarded to the best cooperative. However, producers' incentives to improve quality are still very low as they are paid the same price whatever the quality. To understand this issue, it is important to note that cotton in Mali is graded twice. First, for every producer, seed cotton is weighed and graded at the village-level into three categories. The national producer price set by CMDT is for the best category of seed cotton. Second and third categories are generally paid 10 and 20 CFAF lower per kilogram. In practice however, as it is very difficult to discount the production of a farmer at the village-level, nearly all the production is classified in the best category. ${ }^{8}$ Second, ginned cotton (i.e., cotton lint) is in turn graded

\footnotetext{
7.The daily quotation provided by the Cotlook A Index is an average of the cheapest five offering prices from a selection of sixteen national (or regional) origins traded internationally. For more details, see Larsen, 2003, p.6.

8. Since the CMDT's reform in 2001 (see Wodon et al., 2006), seed cotton has been graded by a few members of the cooperative at the village level, and not by the CMDT's agents (in other words, producers grade their own cotton). In the FT region surveyed for the purpose of this study, all the seed cotton has been classified in the best seed cotton category since 2003 (source: Data collected by the author; see also Tschirley et al., 2009, p.88).
} 
at the factory, and classified into 10 grades (Sarama, Juli/S, Néré, Juli, Kati, Kati/C, Liba, Liba/C, Kola, and Bata, from the best to the worst grade') that are sold at different export prices. Quality premiums are therefore captured by the CMDT through grading and trading practices that are opaque to producers, and that do not encourage them to improve quality (see Bassett, 2010). Indeed, because of the absence of price differentiation according to quality at the primary purchase stage, there are no individual and no immediate incentives to improve it. Quality investment is instead of collective interest since quality premiums should allow the CMDT to secure higher prices for farmers when world market prices fall. However, this collective interest does not encourage producers to invest in quality anymore since in addition to a classic freeriding problem, most growers feel that the stabilization fund resources are mainly used at the discretion of the CMDT to cover deficits of its own making (Badiane, Ghura, Goreux, \& Masson, 2002). By contrast, the FT cotton project in Mali could provide producers' incentives to improve the quality of Malian cotton.

\section{(iii) The solution provided by Fairtrade}

FT cotton in Mali was initiated in 2003 by DAGRIS and Max Havelaar France, the French affiliate of the Fairtrade Labelling Organizations International foundation (hereafter FLO). FLO has developed an international certification system for FT goods. For end-products to carry the 'Fairtrade' label (henceforth Fairtrade) ${ }^{10}$ the entire production chain must be monitored by an independent certification body (FLO-Cert), which ensures that producers, traders, and retailers comply with a number of social, economic and environmental requirements set by FLO. First and foremost, FLO requires the buyers to pay the "Fairtrade price" to producers (that is to say a price fixed by FLO that aims to cover at least production costs), and a "Fairtrade premium" to their cooperatives. In Mali, certified producers are paid $238 \mathrm{CFAF} / \mathrm{kg}$ for seed cotton, and $34 \mathrm{CFAF} / \mathrm{kg}$ go to their organizations. Second, producers have to observe many economic, social, and environmental standards. For example, they have to be organized in a democratic and transparent structure which does not discriminate against any member, invest the Fairtrade premium in order to promote the economic development and the autonomy of their organization, and comply with a number of environmentally sound agricultural practices.

As other Fairtrade projects, the Fairtrade cotton project in Mali was intended to (i) quickly improve the livelihoods of producers in a crisis context, and; (ii) strengthen their organizations (CMDT, 2004). However, CMDT and DAGRIS also viewed Fairtrade as an opportunity to improve the quality of Malian fiber, for three reasons. First, the price differentiation introduced by Fairtrade could be exploited to encourage certified growers to invest in quality upgrading. For this purpose, CMDT and DAGRIS required that only the four best qualities of cotton lint (Sarama, Juli/S, Néré, and Juli) be exported to FT markets. In other words, certified producers receive the Fairtrade price (238 CFAF/kg instead of 165 from 2005/06 to 2007/08, see Table 1 below) only for the part of their

\footnotetext{
9. The grade is a multidimensional indicator which takes into account the color of the lint, and its degree of contamination and stickiness. The quality of the lint also depends on its length, its strength, and its maturity, which are not considered in this paper (for more details on the determinants of the quality of cotton see Larsen, 2003).

10. Throughout the remainder of the paper, "Fair Trade" (FT) refers to the general movement that seeks to offer better trading conditions to producers in developing countries, whereas "Fairtrade" (which is a registered mark owned by FLO) specifically refers to the approach carried out by FLO and its national affiliates. For a detailed description of the FLO's system, see Raynolds (2009).
} 
production which is graded in Sarama, Juli/S, Néré or Juli. This provides them with strong and immediate individual incentives to improve quality. Second, quality should be further improved because of the cooperation and peer-controls that the collective premium (34 CFAF/ $/ \mathrm{kg}$ ) should reinforce." Third, contrary to what occurs in the conventional sector, producers know that the certification process prevents CMDT from capturing the Fairtrade premium by not revealing the true quality of the lint.

This good quality of Fairtrade cotton should reassess the reputation of the Malian fiber. CMDT and DAGRIS actually thought that new clients first attracted by the Fairtrade label would change their perceptions and recognize the good quality of Malian cotton, and then buy (or buy again) conventional Malian cotton (see Giraudy, 2005). Of course, for this reputation-strategy to work, the quality of conventional cotton would have to improve too. Non-certified growers were thus also encouraged to greatly improve the quality of their production. A "Quality Charter" was signed by the CMDT extension agents and the growers' representatives, where the former committed to support producers and the latter promised to apply their recommendations. In other words, FT was expected to have spillover effects on the quality of non-FT famers' production. However, as the Charter has no enforcement value, spillover effects are expected to be restricted to the FT-cooperatives' closest neighborhood. Indeed, as the vast majority of producers distrust CMDT agents, the former are more likely to have confidence in both the reputation-strategy and the CMDT agents' advice if they are close to Fairtrade cooperatives. They could meet FLO agents and inspectors; realize that FT producers effectively gain more, and that CMDT does not reap the benefits of the improved quality. They could also be more confident in the efficiency of the CMDT agents' technical advice by seeing by themselves the quality improvement in FT cooperatives. Besides, producing cotton of as good quality as neighbors' gives "social prestige".

\section{(c) Fair Trade cotton in Mali: Selection of the FT cooperatives and key figures}

An important implication of this strategy concerns the selection process of the FT cooperatives. Cooperatives eligible for certification are pre-selected by CMDT, which chooses those that are thought able to improve quality once certified. The specific objective of promoting quality thus results in an obvious selection bias that complicates the impact evaluation. Unobservable cooperatives' characteristics such as ability, motivation, cooperation, and so forth may drive both the Fairtrade certification and subsequent quality performance. As a consequence, it might be very difficult to disentangle the impact of FT on quality from confounding explanations. However, it should be noted that after the certification of the first four cooperatives for the 2003/04 cotton season, inclusion in FT has been made according to the distance to these first four cooperatives. More precisely, the extension of FT has been made gradually according to the demand for FT cotton (see Table 1 below), and in concentric circles around the first FT cooperatives (see Figure 1 below). This is due to the certification procedure: In Mali, second-degree organizations (the Unions Communales of Kita, Djidian, and Sébékoro) are certified for all or part of their members. It is therefore less costly to first include all the cooperatives of a certified Union Communale. This staggered entry of cooperatives in $\mathrm{FT}$ implies a variation in the treatment over time which

$11.80 \%$ of certified producers actually claim that cooperation has been reinforced since certification (source: Producers' survey, data collected by the author - see endnote 12). 
can be used to solve the selection bias problem (see section 3 ).

The estimation of the impact of FT on quality is further complicated by the expected spillover effects mentioned above, and by the possibility of what is referred to as an "Ashenfelter's dip effect" if the selection is influenced by past value of quality performance. Indeed, if exceptional quality performance in year $t$ determines inclusion in FT in year $t+1$, a natural tendency to mean reversion will yield an underestimate of the impact of FT on quality - what Goldhaber and Anthony (2007) refer to as the "reverse Ashenfelter's dip effect". The next section details the identification strategy designed to estimate the effect of FT on certified and non-certified producers while taking into account the selection bias and spillovers. The possibility of a "reverse Ashenfleter's dip effect" is tested and addressed in section 4.

Table 1. Fair Trade expansion in Mali, 2003/04-2007/08

\begin{tabular}{|c|c|c|c|c|c|}
\hline & \multicolumn{5}{|c|}{ Cotton seasons } \\
\hline & $2003 / 04$ & $2004 / 05$ & $2005 / 06$ & $2006 / 07$ & $2007 / 08$ \\
\hline \multicolumn{6}{|l|}{ Certifications } \\
\hline $\begin{array}{l}\text { Number of newly certified } \\
\text { cooperatives }\end{array}$ & 4 & 12 & 56 & $\mathrm{O}^{(\mathrm{a})}$ & 30 \\
\hline Wave & $1^{\text {st }}$ wave & $2^{\text {nd }}$ wave & $3^{\text {rd }}$ wave & & $4^{\text {th }}$ wave \\
\hline Markers in Fig.1 & $\bullet$ & ○ & - & & $\circ$ \\
\hline $\begin{array}{l}\text { Total number of certified } \\
\text { cooperatives }\end{array}$ & 4 & 16 & 72 & 72 & 102 \\
\hline \multicolumn{6}{|l|}{ Fairtrade production } \\
\hline Seed cotton (tons) & 404 & 1065 & 5816 & 4935 & 3804 \\
\hline Fiber (tons) & 168 & 427 & 2270 & 2191 & 1480 \\
\hline \multicolumn{6}{|l|}{ Fairtrade sales } \\
\hline Fiber (tons) & 57 & 300 & 1608 & 1862 & $\mathrm{O}^{(\mathrm{b})}$ \\
\hline Sales/production ratio & $34 \%$ & $70 \%$ & $71 \%$ & $85 \%$ & ०\% \\
\hline \multicolumn{6}{|c|}{ Producer prices (CFAF/kg of seed cotton) } \\
\hline CDMT price & 200 & 210 & 165 & 165 & 165 \\
\hline Fairtrade price & 238 & 238 & 238 & 238 & 238 \\
\hline
\end{tabular}

Source: CMDT's data, collected by the author in March 2008.

Notes: (a) There was no increase in FT cooperatives in 2006/07 because of lack of demand. (b) In March 2008, Fairtrade cotton had not been sold yet because of lack of demand.

\section{Evaluating the impact of Fair Trade on the quality of Malian cotton: Methodology}

\section{(a) Data}

Data were obtained during a survey I conducted in Mali from January 2008 to March 2008, and cover 198 cooperatives (the 102 certified cooperatives and 96 non-FT cooperatives; see next subsection). They come from different sources. First, data on the quality of cotton were obtained from two ginning factories (Kita and Fana), and from the CMDT sales department (Bamako). 
They cover four cotton seasons (from 2004/05 to 2007/08), and are available for a varying number of cooperatives according to years. For each cooperative, the quantities of seed cotton and cotton lint (itemized by grades) are available. Second, cooperatives' accounts provide a rich dataset of control variables: Areas planted, seed varieties, agrochemicals (fertilizers, pesticides, insecticides) and organic fertilizer uses, rainfall, equipment (carts, ox-drawn ploughs, seeders, motorized cultivators, tractors, draught-cattle), and population. These data have been collected directly from the books of cooperatives, and cover five seasons (from 2003/04 to 2007/08) and all the cooperatives. ${ }^{2}$

\section{(b) Identification strategy}

As explained above, FT was introduced gradually in three Unions Communales (hereafter UC) of the Kita region, according to (i) the demand for Fairtrade cotton, and; (ii) the distance to the first four FT cooperatives (see Figure 1 below). 12 cooperatives of the Djidian and Kita UC were certified in 2004/05. FT was then extended over the region since 44 cooperatives out of the 56 certified in 2005/06 are located in the UC of Sébékoro. No cooperatives were certified in 2006/07. The fourth wave of certification occurred in 2007/08 with 30 more cooperatives included in FT. To assess the impact of FT as well as its spillover effects, the survey covered a fifth group of 96 cooperatives that have been selected to participate in FT but have not yet been certified for lack of demand. Cooperatives on this "waiting list" (indicated by stars on Figure 1) are far from the first FT cooperatives and thus allow the identification of spillover effects on the cooperatives that are not certified but near from certified cooperatives.

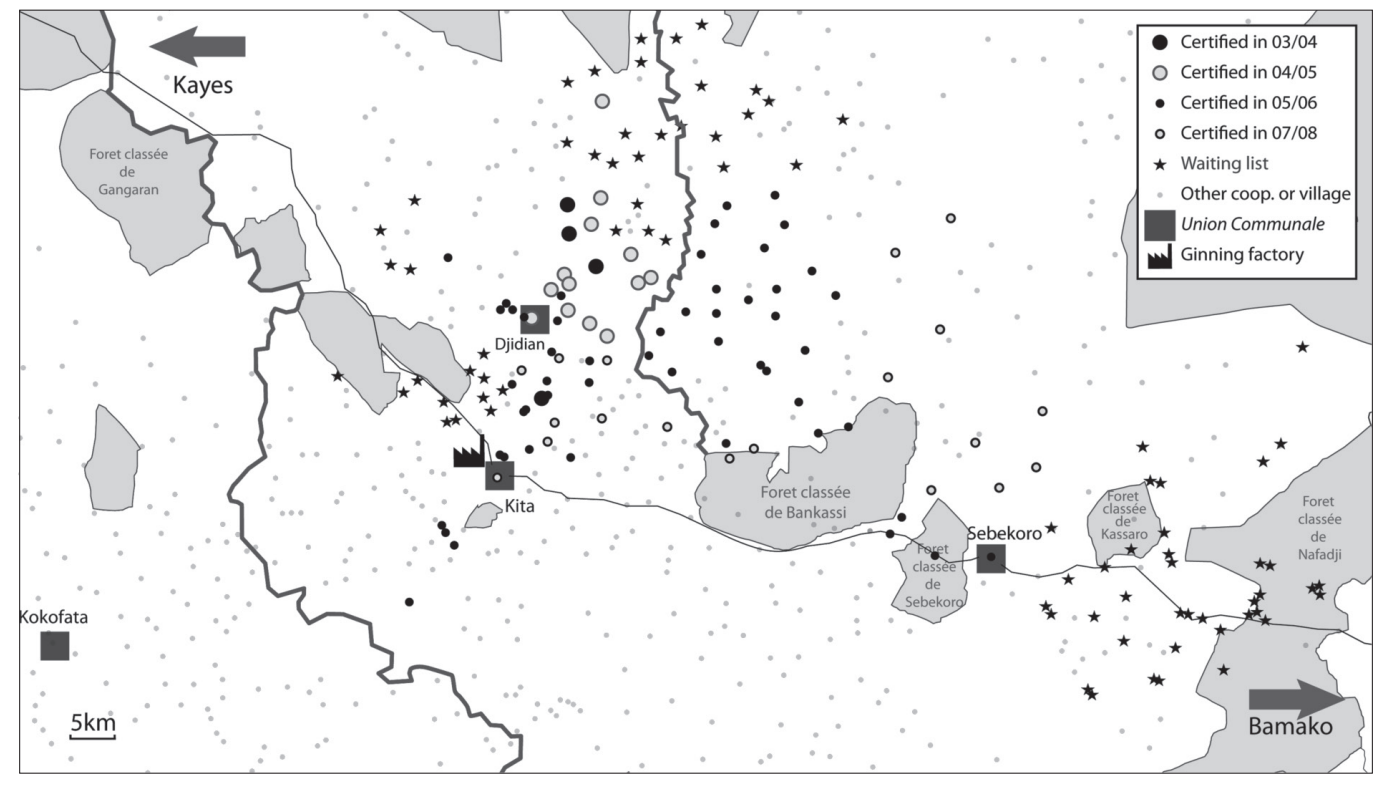

Figure 1. Geographical location of Fairtrade cooperatives.

Notes: All certified cooperatives (indicated by circles) and cooperatives on the waiting list (indicated by stars) are in the sample. Source: Author, from CMDT's document

12. We also surveyed producers to obtain information on the cooperative's organization (number of members, status, and so forth), on board's skills (education of the President, secretary, and treasurer), and on producers' feeling and knowledge. As these variables are not included in the econometric part of this paper, I do not describe them in more details. 
This gradual certification of cooperatives leads to a variation in the treatment over time, which is most helpful to solve the selection bias problem. Indeed, provided that treatment varies over time and that panel data are available (as is the case here), cooperative fixed-effects models control for time-invariant unobservable variables which are supposed to affect both the participation and the outcome, and therefore provide consistent estimates of treatment effects (see Wooldridge, 2002). ${ }^{13}$ The basic empirical specification estimated then takes the following form:

$$
Y_{i, t}=a F T_{i, t}+b\left(1-F T_{i, t}\right) P_{i, t}+c\left(1-F T_{i, t}\right)\left(1-P_{i, t}\right)+\Phi X_{i, t}^{\prime}+\delta_{i}+\lambda_{t}+\varepsilon_{i, t}
$$

Where $Y_{i, t}$ stands for quality performance of the $i^{\text {th }}$ cooperative $(i \in[1,182])$ in the $t / t+1$ cotton season $(t \in[2004,2007]) .{ }^{14}$ Three measures of quality performance are used: (i) The percentage of lint production graded in Sarama, Juli/S, Néré, or Juli (the top four grades required for Fairtrade markets); (ii), the percentage of production graded in Sarama, Juli/S, or Néré (the top three grades), and; (iii) the percentage of production graded in Sarama (the best grade). To simplify, we refer to these three measures as the percentage of Fairtrade qualities (top four), Premium qualities (top three), and Sarama (top), respectively. The treatment variable $F T_{i, t}$ is a dummy variable which takes the value 1 if the $i^{\text {th }}$ cooperative is certified in the $t / t+1^{\text {th }}$ season and o otherwise. What distinguishes treated cooperatives from the others is that the former can sell their products on Fairtrade markets and thus enjoy the Fairtrade price and the cooperative premium. $P_{i, t}$ stands for the proximity of certified cooperatives, and takes the value 1 if there is a certified cooperative located within ten kilometers of cooperative $\mathrm{i}$ in season $t / t+1 .{ }^{15} X_{i, t}$ is a vector of control variables (see Table 3 below). $\delta_{i}$ and $\lambda_{t}$ are cooperatives and period-specific effects, respectively, and $\varepsilon_{i, t}$ is the error term.

Equation (1) includes three dummy variables which correspond to the three following groups: Certified cooperatives $(F T=1)$, cooperatives that are not certified but which are located within ten kilometers of a certified cooperative $(F T=0, P=1)$, and cooperatives that are not certified, and which are far (more than ten kilometers) from a certified cooperative ( $F T=0$, $P=0$ ). In what follows, we refer to these three groups as, $G_{1}, G_{2}$, and $G_{3}$, respectively. Rearranging equation (1) to omit one dummy variable, we get equation (2):

$$
Y_{i, t}=\alpha+\beta_{1} F T_{i, t}+\beta_{2}\left(1-F T_{i, t}\right) P_{i, t}+\Phi X_{i, t}^{\prime}+\delta_{i}+\lambda_{t}+\varepsilon_{i, t}
$$

Where $\alpha=c, \beta_{1}=a-c$, and $\beta_{2}=b-c$. If control groups are good counterfactuals, $\beta_{1}$ is the "overall" impact of $F T$, that is to say the difference between the average quality produced in $\mathrm{G}_{1}$ (certi-

13. The idea, often referred to as the "pipeline approach" (Ravallion, 2005, p.30), is to take cooperatives yet to be included in FT as control group. As these cooperatives have been selected to participate in FT but have not yet been certified, they should constitute a valid comparison group as they are probably a good approximation of what would have happened in certified cooperatives in the absence of FT. The key assumption behind this approach is that the timing of treatment is exogenous (as is the case here since FT extension depends on Northern demand and on the distance from the first FT cooperatives).

14. Because data on quality are not available before their inclusion in FT, the first two waves are excluded from the regressions (imax = 182).

15. Results are unaffected by the choice of other proximity variables (five instead of ten kilometers for example, or the number of FTcooperatives in such a neighborhood instead of a dummy variable, see Miguel \& Kremer, 2004). It should be noted that this identification strategy may be subject to spatial autocorrelation. Unfortunately, the absence of GPS data prevents us from applying recent developments in spatial econometrics to test if spillover effects are due to unobservable FT zone characteristics. However, these may be included in cooperatives characteristics (soil quality for example). 
fied cooperatives) and the one produced in $\mathrm{G}_{3}$ (distant non-certified cooperatives, see Figure 2 below). $\beta_{2}$ captures spillover effects, that is to say the difference between quality produced in $\mathrm{G} 2$ and the one produced in $\mathrm{G}_{3}$. The specific impact of FT certification is thus given by $\beta_{1}-\beta_{2}$.

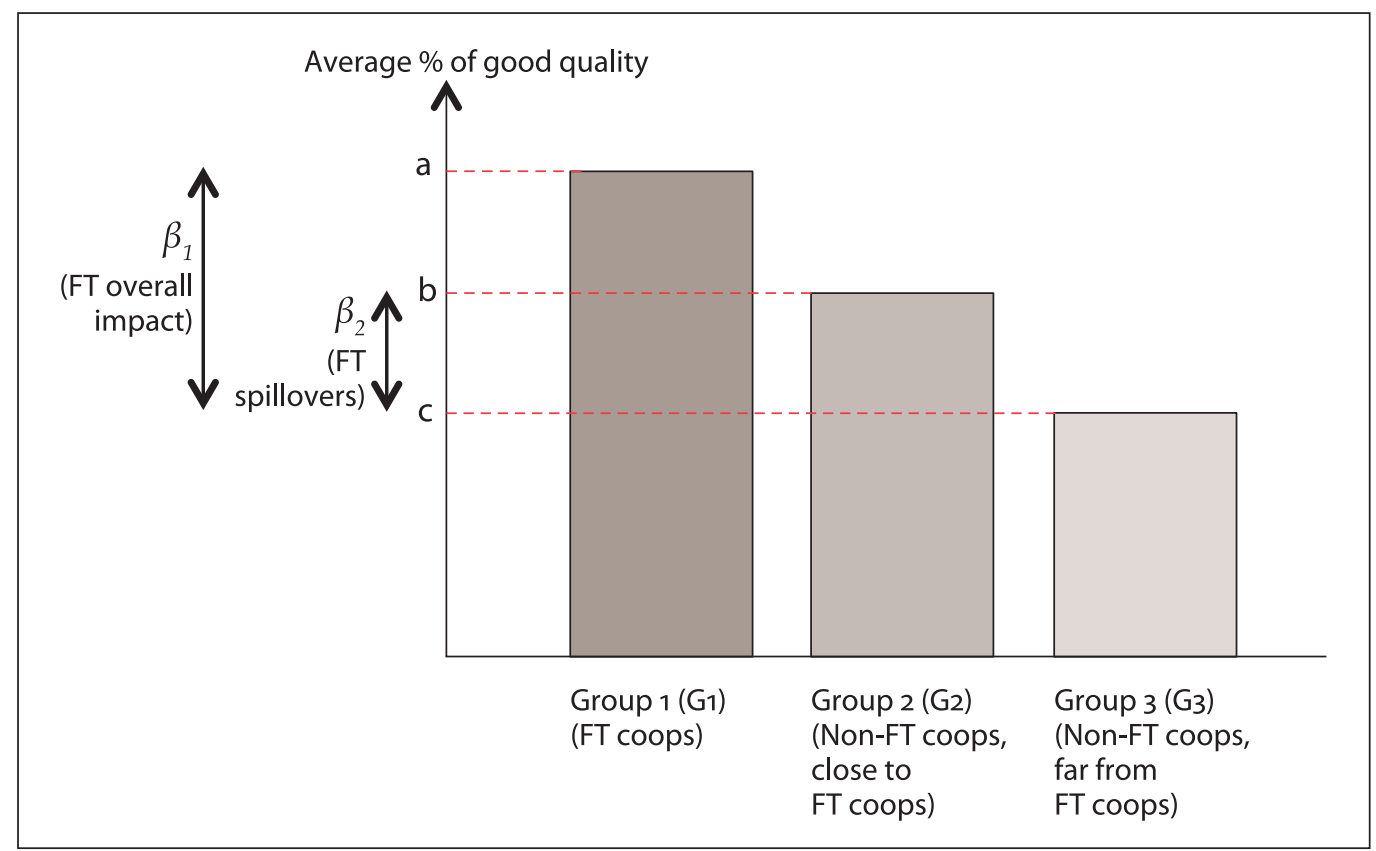

Figure 2. Expected effects of Fair Trade on the quality on Malian cotton.

Source: Author, adapted from Janssens, 2006.

To assess the validity of control groups ( $G_{3}$ is a good counterfactual for $G_{2}$, the latter being a counterfactual group for $\mathrm{G}_{1}$ ), the next sub-section tests the parallel trend assumption on which difference-in-differences techniques rely.

\section{(c) Testing for the parallel trend assumption}

The identification strategy described above relies on the key assumption that, in the absence of $F T$, the change in quality in control groups ( $\mathrm{G}_{2}$ or $\mathrm{G}_{3}$ ) would have been the same as in the treated groups ( $\mathrm{G}_{1}$ - being certified, or $\mathrm{G}_{2}$ - becoming near to a certified cooperative). While this assumption cannot be tested directly, we can test whether the trends in control and treatment groups are the same in the pre-treatment periods. The availability of the data allows to compare the evolution of quality between the group of cooperatives certified in 2007/08 (the "fourth wave", which stands for $\mathrm{G}_{1}$ ) and the two others groups (neighboring non-FT cooperatives, G2; and distant non-FT cooperatives, G3) between 2004/2005 and 2006/07. The left-hand side part of Figure 3 below suggests similar trends for Fairtrade qualities. However, it seems that the percent of Premium qualities produced by the fourth wave was better than the average the year before its certification (see middle part of Figure 3, Panels A, B, and C). Non-FT cooperatives which are close to a certified cooperative display similar trends in quality as other non-FT cooperatives, except for Sarama (see Figure 3, Panel D). 


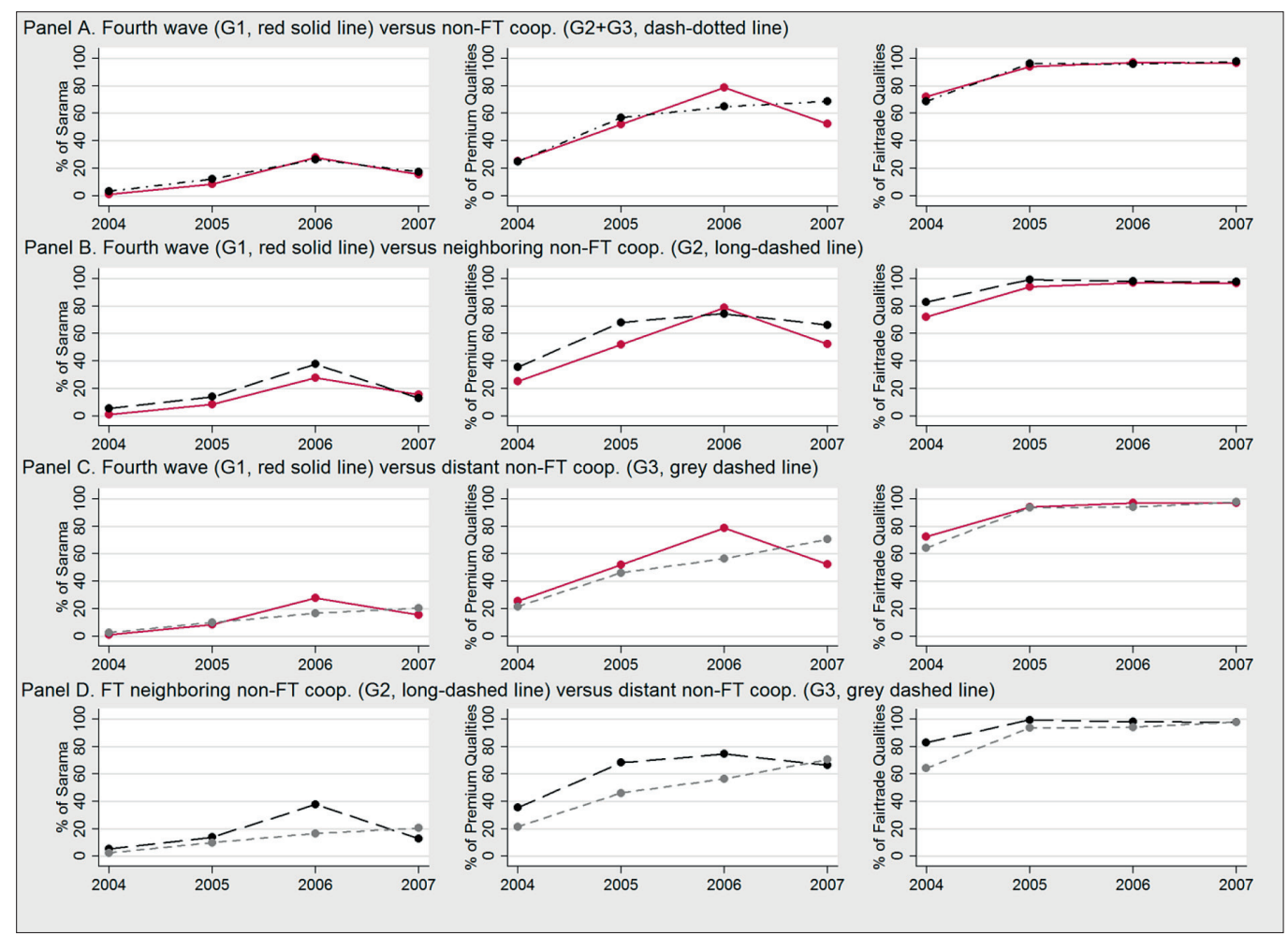

Figure 3. Evolution of quality in FT versus non-FT cooperatives.

Notes: The fourth wave was certified in 2007/08. Year $\mathrm{t}$ stands for season $\mathrm{t} / \mathrm{t}+1$. Sarama $=$ best grade of cotton lint; Premium qualities $=$ top three grades; Fairtrade qualities $=$ top four grades.

Source: Author, from CMDT's data

Following Galiani, Gertler, and Schargrodsky (2005), I test the parallel trend assumption on pretreatment periods by estimating different versions of equation (2). First, I only use the observations of the control and the treatment cooperatives before the certification of the fourth wave (that is before 2007/08). I then modify equation (2) by excluding the FT variable and including separate year dummies for eventual treatment and controls, which yields equation (3):

$$
Y_{i, t}=\alpha+\sum_{t=2005}^{2006} \beta_{t} t+\sum_{t=2005}^{2006} \eta_{t}(t \times 1[i \in \text { fourth wave }])+\delta_{i}+\varepsilon_{i, t}
$$

Where $t$ denotes year $t$ of the $t / t+1$ cotton season (the dummy for the 2004/05 season is omitted). $1[\mathrm{~A}]$ is the indicator variable for event $A$ (in this case, a dummy variable that takes the value 1 if the cooperative $i$ belong to the fourth wave, o otherwise). As in equation (2), $\delta_{i}$ are cooperatives fixed-effects, and $\varepsilon_{i, t}$ is the error term. I test the hypothesis that the pre-certification year dummies are the same for the control groups and the eventual fourth wave by testing the joint significance of the $\eta$ coefficients. The F-statistics for the joint significance are reported in Table 2 below (a value in bold indicates that the corresponding Ho is rejected). Parts A, B, and $C$ indicate that we cannot statistically reject the hypothesis that the pre-certification dummies are the same for both the control and eventual certified cooperatives at conventional levels of statistical significance for Fairtrade qualities. However, they suggest that cooperatives certified in 2007/08 produced more Premium qualities (and, to a lesser extent, more Sarama) than controls before their certification, confirming that a reverse Ashenfleter's dip has to be taken into 
consideration while estimating equation (2). However, Part D of Table 2 indicates that changes in quality in non-FT cooperatives have been the same, whatever their eventual distance to FT cooperatives in 2007/08.

Table 2. Testing for the parallel trend assumption

Part A. HO: quality in the $4^{\text {th }}$ wave and in non-certified coops has evolved in the same way between 2004/05 and 2006/07 (see also Figure 3, Panel A)

\begin{tabular}{l|l|l|l}
\hline Quality & Sarama & Premium & Fairtrade \\
\hline F-stat $(2,276)$ & 1.368 & $\mathbf{3 . 5 4 0}$ & 0.418 \\
\hline
\end{tabular}

Part B. H0: quality in the $4^{\text {th }}$ wave and in neighboring non-certified coops has evolved in the same way between 2004/05 and 2006/07 (see also Figure 3, Panel B)

\begin{tabular}{l|l|l|l}
\hline Quality & Sarama & Premium & Fairtrade \\
\hline F-stat $(2,169)$ & 0.133 & $\mathbf{3 . 6 0 1}$ & 1.435 \\
\hline
\end{tabular}

Part C. HO: quality in the $4^{\text {th }}$ wave and in distant non-certified coops has evolved in the same way between 2004/05 and 2006/07 (see also Figure 3, Panel C)

\begin{tabular}{l|l|l|l}
\hline Quality & Sarama & Premium & Fairtrade \\
\hline F-stat $(2,215)$ & $\mathbf{7 . 7 9 5}$ & $\mathbf{4 . 1 3 6}$ & 1.392 \\
\hline
\end{tabular}

Part D. HO: quality in the in FT-neighboring non-certified coops and distant non-certified coops has evolved in the same way between 2004/05 and 2006/07 (see also Figure 3, Panel D)

\begin{tabular}{l|l|l|l}
\hline Quality & Sarama & Premium & Fairtrade \\
\hline F-stat $(2,177)$ & 1.079 & 1.703 & 0.875
\end{tabular}

Notes: The critical values of $\mathrm{F}(2, \infty)$ are 4.61 (99\% probability level), 3.00 (95\%), and $2.30(90 \%)$. The null hypothesis (Ho) can be rejected at the corresponding level of confidence when the critical value is lower than the observed value (these cases are indicated in bold). The $4^{\text {th }}$ wave was certified in 2007/08.

Sarama $=$ best grade of cotton lint; Premium = top three grades; Fairtrade = top four grades

\section{Results}

\section{(a) Basic results}

Table 3 contains the results of the fixed-effects estimations of equation (2). Two important determinants of the quality of cotton are included: Rainfall (in millimeters), and the variety of seed used where CS ("cleaned seed") is an indicator variable which takes the value 1 if the cooperative is provided with seed cleaned from seed-coat fragments. Results suggest that FT has only a limited impact on cotton quality, if not negative. ${ }^{16}$ Besides, it is difficult to disentangle the overall effect of FT ( $\beta_{1}$ ) from its spillover effects ( $\left.\beta_{2}\right)$ : While only $\beta_{1}$ of column (1) appears to be statistically significant, the $p$-value of $\beta_{2}$ is close to $10 \%$ too and, more importantly, $\beta_{2}$ is not statistically different from $\beta_{1}$.

\footnotetext{
16. Results are unaffected by the choice of alternatives specifications (e.g. logarithmic transformation of the dependent variable) or the choice of estimators (on Tobit versus Ordinary Least Squares estimators with a limited dependent variable see Wooldridge, 2002, p.517).
} 
Table 3. The impact of Fair Trade on cotton quality: Basic results (within estimates of equation (2))

\begin{tabular}{|c|c|c|c|}
\hline \multirow[b]{2}{*}{$\begin{array}{l}\text { Right hand-side variables } \\
\text { (corresponding coefficient } \\
\text { in eq. 2) }\end{array}$} & \multicolumn{3}{|c|}{ Left hand-side variables } \\
\hline & $\begin{array}{c}\text { \% of Sarama } \\
\text { (1) }\end{array}$ & $\begin{array}{l}\text { \% of Premium } \\
\text { qualities } \\
\text { (2) }\end{array}$ & $\begin{array}{l}\% \text { of Fairtrade qualities } \\
\text { (3) }\end{array}$ \\
\hline$F T\left(\beta_{1}\right)$ & $\begin{array}{l}6.797^{*} \\
(3.858)\end{array}$ & $\begin{array}{l}-3.134 \\
(6.659)\end{array}$ & $\begin{array}{l}-2.868 \\
(5.166)\end{array}$ \\
\hline$(1-F T) P\left(\beta_{2}\right)$ & $\begin{array}{l}5.178 \\
(3.904)\end{array}$ & $\begin{array}{l}4.534 \\
(5.865)\end{array}$ & $\begin{array}{l}1.043 \\
(4.519)\end{array}$ \\
\hline CS & $\begin{array}{l}20.717^{* * *} \\
(5.910)\end{array}$ & $\begin{array}{l}29.648^{* * *} \\
(7.085)\end{array}$ & $\begin{array}{l}9.485^{* * *} \\
(3.334)\end{array}$ \\
\hline Rainfall (mm) & $\begin{array}{l}0.017 \\
(0.021)\end{array}$ & $\begin{array}{l}-0.030 \\
(0.021)\end{array}$ & $\begin{array}{l}-0.004 \\
(0.009)\end{array}$ \\
\hline $2004 / 05$ & $\begin{array}{l}0.145 \\
(7.821)\end{array}$ & $\begin{array}{l}-43.116^{* * *} \\
(9.493)\end{array}$ & $\begin{array}{l}-24.354^{* * *} \\
(5.292)\end{array}$ \\
\hline $2005 / 06$ & $\begin{array}{l}-0.634 \\
(2.687)\end{array}$ & $\begin{array}{l}-1.267 \\
(3.999)\end{array}$ & $\begin{array}{l}2.036 \\
(1.665)\end{array}$ \\
\hline $2006 / 07$ & $\begin{array}{l}18.342^{* * *} \\
(4.784)\end{array}$ & $\begin{array}{l}1.496 \\
(5.581)\end{array}$ & $\begin{array}{l}0.858 \\
(2.342)\end{array}$ \\
\hline Constant & $\begin{array}{l}-10.069 \\
(21.113)\end{array}$ & $\begin{array}{l}89.888^{* * *} \\
(22.496)\end{array}$ & $\begin{array}{l}99.148^{* * *} \\
(10.465)\end{array}$ \\
\hline Coop. fixed effects & Yes & Yes & Yes \\
\hline Number of observations & 603 & 603 & 603 \\
\hline Number of cooperatives & 182 & 182 & 182 \\
\hline$R^{2}$ & 0.21 & 0.30 & 0.34 \\
\hline
\end{tabular}

Notes: robust standard deviations in parentheses. ${ }^{*}$ significant at $10 \%,{ }^{* *}$ significant at $5 \%,{ }^{* * *}$ significant at $1 \%$. All variables, except rainfall in millimeters, are dummy variables taking of value of 1 if condition is satisfied. The total number of observations is not equal to $728\left(182^{*}\right)$ because the availability of data varies according to years.

Sarama $=$ best grade of cotton lint; Premium qualities $=$ top three grades; Fairtrade qualities $=$ top four grades.

These results appear counter-intuitive and go against other findings and impressions from knowledgeable people in the field. According to extension agents and producers, quality improved so much that the local expression for "Fairtrade cotton" is "Sarama cotton". Moreover, while the vast majority of certified producers do not know any Fairtrade standards, $90 \%$ know that they must improve the quality of cotton to get the Fairtrade price. ${ }^{17}$

These results can be explained in two ways: Either these results are the true results, and they reflect the selection bias of certified cooperatives; $;{ }^{18}$ or the identification strategy used so far misestimates the impact of FT on quality. For example, it could be that FT has spillover effects outside the ten kilometers zone defined by our variable P. Unfortunately, because of the absence of GPS

17. Sources: Informal interviews with CMDT agents and producers' survey (see endnote 12).

18. Producers might also believe that FT certification depends on quality improvement, and hence do their best to improve quality. Once certified, they might relax their efforts so FT certification would lead to a decrease in quality. However, the producers' survey (see endnote 12) shows that, in 2008, non-FT producers do not know anything about FT or FT criteria. It is therefore justifiable to think that it was all the more so in 2004 and 2005 when FT was new in the region. 
data, we cannot use another variable. Besides, as already suggested, a "reverse Ashenfleter's dip effect" (Goldhaber \& Anthony, 2007) might result in the impact of FT being understated. The next subsection checks for this possibility.

\section{(b) Testing for a reverse Ashenfelter's dip effect}

Panel fixed-effects regressions generalize the difference-in-differences estimator when there are more than two periods and more than two groups (Duflo, 2002). However, these estimators are not valid if the program is implemented based on pre-existing differences in outcomes. For example, Ashenfleter (1978) and Ashenfleter and Card (1985) identified that many participants in training programs experience a dip in earnings just before they enter the program, which may explain why they enter the program in the first place (Duflo, 2002). If the pre-program drop in earnings is transient, difference-in-differences estimates overstate the impact of training programs, as the increase in earnings observed just after the program may be partly due to a mean reversion process (Heckman \& Smith, 1999). In our case however, we are led to assume the existence of a "reverse" Ashenfleter's dip effect. ${ }^{19}$ If a temporarily higher quality performance has caused the Fairtrade-certification of Malian cooperatives, a natural tendency towards mean reversion could explain why no effect appears just after the certification. To explore this possible explanation I follow the two-step approach used by Chay, McEwan, and Urquiola (2005), examining first if the quality produced in $\mathrm{t}-1$ determines the inclusion in $\mathrm{FT}$ in $\mathrm{t}$, and then studying if there is a mean reversion process.

\section{(i) Is quality a selection criterion?}

Contrary to the school program assistance studied by Chay et al. (2005), pretreatment value of the outcome variable (average students' test scores in their case, cotton quality in ours) is not an official selection criterion to be Fairtrade-certified. As explained above, certification depends on consumer demand for FT cotton, and is extended first to cooperatives which are (i) members of a certified Union Communale, and; (ii) close to certified cooperatives. However, if in a given year the demand was not sufficient to include all eligible cooperatives, it might have been that only cooperatives which produced the best quality in the previous year were eventually certified. To see if this is the case Figure 4 plots the percentage of quality-grade produced in 2004/05 by the 182 non-FT cooperatives against their FT status in 2005/06 (Panel A), and the quality-grade produced in 2006/07 by the 126 non-FT cooperatives against their FT status in 2007/08 (Panel B). According to Panel A, only the share of Fairtrade qualities seems to have influenced the selection in 2005/06. Leaving aside the two cooperatives that produced only $10 \%$ of Fairtrade quality cotton in $2004 / 05,29 \%$ seems to be a quality threshold below which certification was not possible. It should be noted that selection is stricter given that certification was not given to all cooperatives that produced more than $29 \%$ of Fairtrade quality cotton in $2004 / 05$, confirming that distance

\footnotetext{
19. Studying the relationship between teachers' abilities and student achievement, Goldhaber and Anthony (2007) use this expression to describe the following situation: Teachers who have gained recognition for their knowledge and teaching skills through a voluntary certification process may appear less effective than others if a temporary increase in their performance has encouraged them to apply for certification.
} 
and demand limit the inclusion. In 2007/08 (Figure 4, Panel B), the correlation between quality performance in t-1 and certification in t is more obvious: Only cooperatives that produced more than $51 \%$ of Premium qualities and/or $86 \%$ of Fairtrade qualities in 2006/07 were certified in 2007/08. In sum, if there is a correlation between quality produced in $t-1$ and certification in $t$, only Premium and Fairtrade qualities seem to be concerned. ${ }^{20}$ This result is consistent with those contained in Tables 2 and 3.

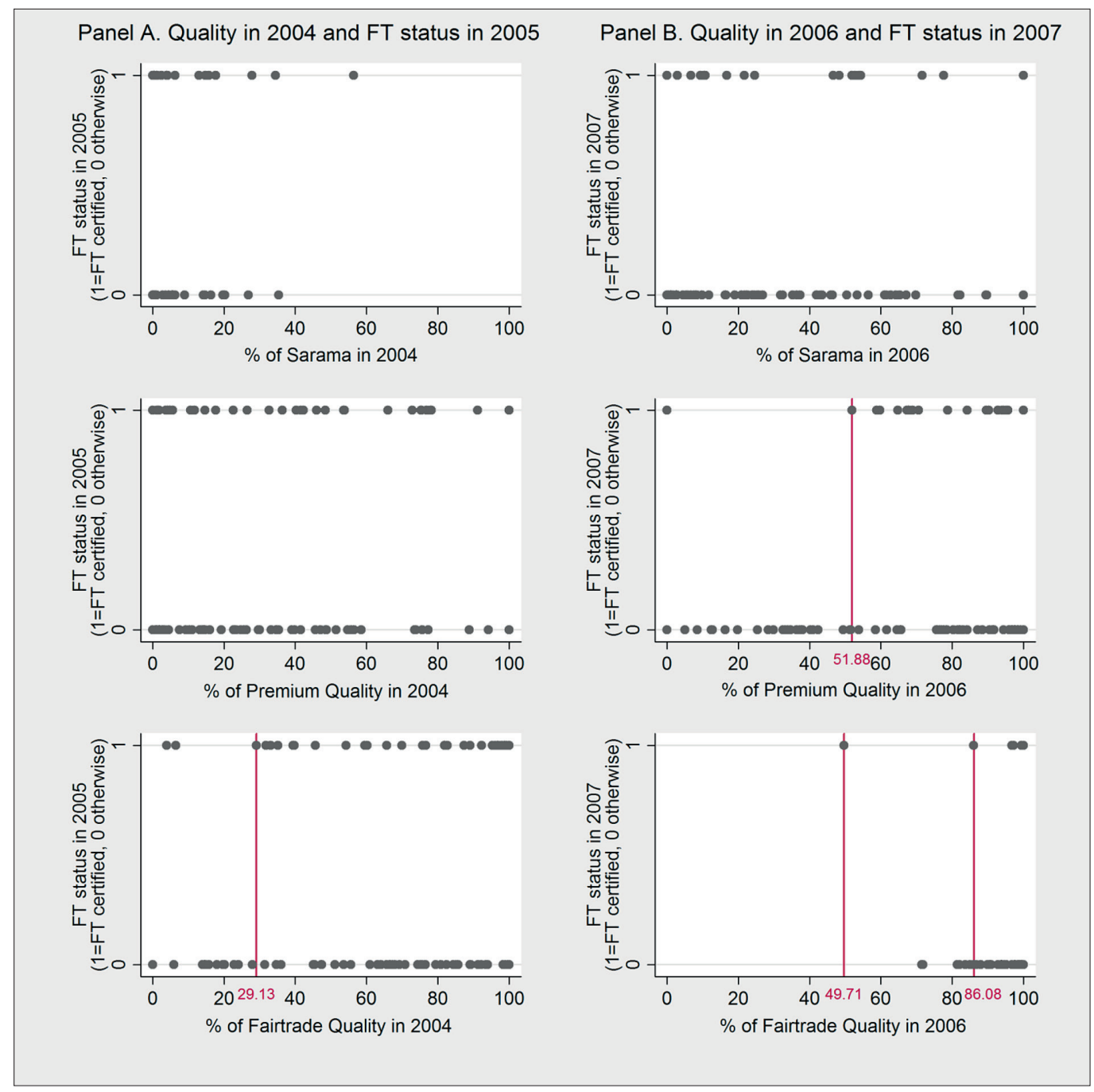

Figure 4. Quality in year t versus FT status in $t+1$.

Notes: Year $\mathrm{t}$ stands for season $\mathrm{t} / \mathrm{t}+1$. Panel A plots the quality produced in $2004 / 05$ by the 182 non-FT cooperatives against their $\mathrm{FT}$ status in 2005/06. Panel B plots the quality produced in 2006/07 by the 126 non-FT cooperatives against their FT status in 2007/08. Due to overlap or to the availability of data on quality, all 182 (resp. 126) coops (indicated by dots) are not visible in Panel A (resp. Panel B), especially for Sarama as the percent of the production graded in Sarama is zero for many coops.

Sarama $=$ best grade of cotton lint; Premium qualities $=$ top three grades; Fairtrade qualities $=$ top four grades. Source: Author, from CMDT's data 


\section{(ii) Evidence on mean reversion}

This better-than-average pre-certification quality performance of certified cooperatives may lead our fixed-effect regressions to understate the true effect of $F T$ if, and only if, this quality performance is transient (due for example to exceptional climatic conditions or to less pest infestation). In that case, since these lucky circumstances are unlikely to reproduce in $t$, the average quality performance in $t$ will tend to be lower than in $t-1$. This phenomenon should result in a peak in average quality the year before certification as is shown by Figure 3 above, especially for Premium qualities (middle column of Figure 3 ).

I test for the existence and the significance of a mean reversion process by applying a "false treatment" as in Chay et al. (2005). To do this, I first retain the threshold identified above in Figure 4 Panel A as a certification criterion for 2005/06 (Fairtrade qualities $\geq 29.13 \%$ ). Then, I identify a sample of 76 cooperatives which were not certified or subject to spillover effects in 2004/05 and 2005/06, and divide this sample in two groups according to the quality performance achieved in 2004/05: Those who produced more or $29.13 \%$ of Fairtrade qualities cotton in $2004 / 05$ are considered as "treated" ( $T$ ) in 2005/06. Lastly, l estimate the impact of this "false treatment" using the difference-in-differences estimator ( $\eta$ in equation (4.a)).

$$
Y_{i, t}=\alpha+\beta \cdot 1[t=2005]+\gamma \cdot 1[i \in T]+\eta \cdot 1[t=2005] \times 1[i \in T]+\varepsilon_{i, t}
$$

Where $1[A]$ is the indicator variable for the event $A$. As there are no expected Fairtrade effects (due to certification or spillovers) for these cooperatives at that time, this false treatment should yield no effect ( $\eta$ should be zero), unless driven by mean reversion.

I also apply a false treatment in 2007/08 to 41 out of 57 cooperatives which were not certified or subject to spillovers in 2006/07 by retaining the thresholds identified in Figure 4 Panel B (51.88\% of Premium qualities and $49.71 \%$ or $86.08 \%$ of Fairtrade qualities). The effects of these fictitious treatments are given by coefficients $\eta$ ' in equation (4.b).

$$
Y_{i, t}=\alpha^{\prime}+\beta^{\prime} \cdot 1[t=2007]+\gamma^{\prime} \cdot 1[i \in T]+\eta^{\prime} \cdot 1[t=2007] \times 1[i \in T]+\varepsilon_{i, t}
$$

Table 4 gives the different estimates of coefficients $\eta$ and $\eta^{\prime}$ according to the selection criterion retained and the outcome variable $(Y$ could be the percent of Sarama, Premium or Fairtrade qualities). The sign, size and significance of the estimated $\eta$ and $\eta^{\prime}$ suggest that mean reversion is actually of primary importance. The next subsection presents an adapted identification strategy and its results. 
Table 4. Testing for a mean reversion process

\begin{tabular}{|c|c|}
\hline \multicolumn{2}{|c|}{$\begin{array}{l}\text { Part A. Impact of a false treatment applied in } 2005 / 06 \text { to cooperatives which produced } \\
\text { more than } 29.13 \% \text { of Fairtrade qualities in } 2004 / 05 \text { ( } \eta \text { in equation } 4 . a \text { ) }\end{array}$} \\
\hline Left hand-side variables & Estimates of $\eta$ \\
\hline$\%$ of Sarama & $2.132(4.266)$ \\
\hline$\%$ of Premium qualities & $-26.181(9.353)^{* * *}$ \\
\hline$\%$ of Fairtrade qualities & $-65.172(4.733) * * *$ \\
\hline \multicolumn{2}{|c|}{$\begin{array}{l}\text { Part B. Impact of a false treatment applied in } 2007 / 08 \text { to cooperatives which produced } \\
\left.\text { more than } 51.88 \% \text { of Premium Qualities in } 2006 / 07 \text { ( } \eta^{\prime} \text { in equation } 4 . b\right)\end{array}$} \\
\hline Left hand-side variables & Estimates of $\eta^{\prime}$ \\
\hline$\%$ of Sarama & $-15.254(10.425)$ \\
\hline$\%$ of Premium qualities & $-52.100(9.700)^{* * *}$ \\
\hline$\%$ of Fairtrade qualities & $-9.064(3.429)^{* * *}$ \\
\hline \multicolumn{2}{|c|}{$\begin{array}{l}\text { Part C. Impact of a false treatment applied in } 2007 / 08 \text { to cooperatives which produced } \\
\left.\text { more than } 49.71 \% \text { of Fairtrade Qualities in } 2006 / 07 \text { ( } \eta^{\prime} \text { in equation } 4 . b\right)\end{array}$} \\
\hline Left hand-side variables & Estimates of $\eta^{\prime}$ \\
\hline$\%$ of Sarama & $-19.762(10.018)^{* *}$ \\
\hline$\%$ of Premium qualities & $-352.431(10.110)^{* * *}$ \\
\hline$\%$ of Fairtrade qualities & $-44.084(2.432)^{* * * *}$ \\
\hline \multicolumn{2}{|c|}{$\begin{array}{l}\text { Part D. Impact of a false treatment applied in } 2007 / 08 \text { to cooperatives which produced } \\
\text { more than } 86.08 \% \text { of Fairtrade Qualities in } 2006 / 07 \text { ( } \eta^{\prime} \text { in equation } 4 . b \text { ) }\end{array}$} \\
\hline Left hand-side variables & Estimates of $\eta^{\prime}$ \\
\hline$\%$ of Sarama & $-6.576(12.208)$ \\
\hline$\%$ of Premium qualities & $-18.346(15.402)$ \\
\hline$\%$ of Fairtrade qualities & $-22.601(5.340)^{* * *}$ \\
\hline
\end{tabular}

Notes: robust standard deviations in parentheses. ${ }^{*}$ significant at $10 \%,{ }^{* *}$ significant at $5 \%,{ }^{* * *}$ significant at $1 \%$. Sarama $=$ best grade of cotton lint; Premium qualities = top three grades; Fairtrade qualities $=$ top four grades

\section{(c) Refined results: Lower and upper bounds of the impact of FT}

The regression discontinuity approach applied by Chay et al. (2005) to address the mean reversion phenomenon is not applicable in our case as there is not a strict threshold (besides, quality is not an official selection criterion). Following Angrist and Pischke (2009), I thus introduced the lagged dependent variable in equation (2), leading to equation (5).

$$
Y_{i, t}=\alpha+\theta Y_{i, t-1}+\beta_{1} F T_{i, t}+\beta_{2}\left(1-F T_{i, t}\right) P_{i, t}+\Phi X_{i, t}^{\prime}+\delta_{i}+\lambda_{t}+\varepsilon_{i, t}
$$

Due to the correlation between the lagged dependent variable and the fixed effects, equation (5) cannot be estimated by Ordinary Least Squares (OLS) (see Cameron \& Trivedi, 2005). I thus estimated equation (5) with the Generalized Methods of Moments in system (GMM system) as developed by Arellano and Bover (1995) and Blundell and Bund (1998). However, results are not conclusive: The over-identification Hansen test leads to reject the validity of instruments, and only the results for Fairtrade qualities are robust to the modification of instruments. ${ }^{21}$

21. Furthermore, one could have serious concern about the absence of serial correlation. 
Given the inconclusive results of the GMM system estimations, I finally estimated a lower and an upper bound for the impact of FT, as suggested by Angrist and Pischke (2009) to address Ashenfelter's dip effects (or, more generally, to deal with the difficulties in estimating a dynamic panel data model). ${ }^{22}$ They actually demonstrate that "fixed effects and lagged dependent variables estimates have useful bracketing property" (ibid., p.245). Applied to our case, this property leads to the following: The estimated effect of the treatment variable (FT) with fixed-effects but without the lagged dependent variable (equation (2), reproduced below) is a lower-bound because we do not control for the mean reversion process, as our reverse Ashenfelter's dip hypothesis leads us to assume in the previous subsection. On the contrary, the estimates of $\beta$ with lagged dependent variable but ignoring fixed-effects (as in equation (6) below) provide an upper-bound as they overstate the impact of FT as we do not take into account unobservable characteristics that are positively correlated with quality performance.

$$
\begin{gathered}
Y_{i, t}=\alpha+\beta_{1} F T_{i, t}+\beta_{2}\left(1-F T_{i, t}\right) P_{i, t}+\Phi X_{i, t}^{\prime}+\delta_{i}+\lambda_{t}+\varepsilon_{i, t} \quad \text { (eq. 2, lower bound) } \\
Y_{i, t}=\alpha+\theta Y_{i, t-1}+\beta_{1} F T_{i, t}+\beta_{2}\left(1-F T_{i, t}\right) P_{i, t}+\Phi X_{i, t}^{\prime}+\lambda_{t}+\varepsilon_{i, t} \quad \text { (eq.6, upper bound) }
\end{gathered}
$$

Thus, estimating equation (2) with the first-difference or within estimator provides the minimum impact of FT (lower bound), and the OLS estimate of equation (6) provides the maximum impact of FT (upper bound). Table 5 gives these such lower and upper bound estimates suggesting that FT accounted for at least half of the quality improvement in the FT zone.

Table 5. Upper and lower bounds of the impact of Fair Trade on cotton quality (in percentage points)

\begin{tabular}{l|l|l|l|c}
\hline & \multicolumn{2}{|c|}{ Overall impact (estimates of $\left.\beta_{1}\right)$} & \multicolumn{2}{c}{ Spillover effects (estimates of $\beta_{2}$ ) } \\
\hline & $\begin{array}{l}\text { Upper bound } \\
(1)\end{array}$ & $\begin{array}{l}\text { Lower bound } \\
(2)\end{array}$ & $\begin{array}{l}\text { Upper bound } \\
(3)\end{array}$ & $\begin{array}{l}\text { Lower bound } \\
(4)\end{array}$ \\
\hline Sarama & $+7,699^{* * *}$ & $\begin{array}{l}+6,797^{*} \\
\left(+6,890^{*}\right)\end{array}$ & $+9,656^{* * *}$ & $\begin{array}{l}+5,178^{*} \\
\left(+7.429^{* *}\right.\end{array}$ \\
\hline Premium qualities & $+7,991^{* *}$ & Null $^{\text {(a) }}$ & $9,417^{* *}$ & Null (a) \\
\hline Fairtrade qualities & $+2,380^{*}$ & Null (a) & $+2,603^{* *}$ & Null (a) \\
\hline
\end{tabular}

Notes: coefficients of columns (1) and (3) are OLS estimates of $\beta_{1}$ and $\beta_{2}$ in equation (6). Coefficients of columns (2) and (4) are within estimates of $\beta_{1}$ and $\beta_{2}$ in equation (2) (first-differences estimates in parentheses in columns (2) and (4)).

(a) Null means not statistically different from zero.

* significant at 10\%, ** significant at $5 \%,{ }^{* * *}$ significant at $1 \%$.

Sarama = best grade of cotton lint; Premium qualities = top three grades; Fairtrade qualities = top four grades

Note that the previous within estimates are consistent as they are comprised between the estimated bounds, and that these bounds are quite close lending support that they are plausible estimates. The estimates suggest that FT induces a 7 percent points (pp) increase in the proportion of Sarama cotton in certified cooperatives, and a $5 \mathrm{pp}$ rise in the cooperatives subject to spillover effects. At the very best, FT induces a 8-9pp increase in Sarama and Premium qualities, and a $2.5 \mathrm{pp}$ increase in Fairtrade qualities, and spillovers and overall effects are similar. In other

22. For an empirical application, see Head \& Ries (2010). 
words, FT accounts for at least half of the quality improvement observed in the FT zone (where the proportion of Sarama increased from 3\% in 2004/05 to 16\% in 2007/08 whereas the Malian average increased from $1.4 \%$ to $3.7 \%$ ). Had this improvement concerned the whole cotton sector, it would have increased the CMDT's $2007 / 08$ turnover by 250 million CFAF (0.4\% of its 2007/08 turnover). ${ }^{23}$

\section{Implications and conclusion}

Controlling for selection bias and the possibility of a reverse Ashenfleter's dip effect, this study finds that FT has a significant impact on the quality of cotton produced in Mali. These results are in line with those of other studies on FT cotton in West Africa (Bassett, 2010). ${ }^{24}$

This quality upgrading can be accounted for by reduced uncertainty and enhanced incentives provided to producers. ${ }^{25} \mathrm{FT}$ actually introduces two equally important factors that encourage producers to improve quality: Price differentiation and third-party certification, which fosters producers' trust in contract enforceability. Because improving quality is time-costly, and thereby increases production costs, price differentiation is a necessary condition, but not sufficient in itself. Guarantees provided by FLO-Cert, who checks both the price paid by the CMDT to FT producers and cotton grading, reduce growers' uncertainty from engaging in quality improvement. In this sense, the results presented here corroborate the importance of independent third-parties in reducing small producers' uncertainty about the net returns to engage in quality upgrading highlighted by Torero and Viceisza (2011) in a Vietnamese dairy, and by Bolwig et al. (2009) in the context of organic contract farming in Uganda.

Though project-specific, these findings have two main implications. First, while the future of West African cotton is a "question of quality" (Bingen, 2006, p.219) and, more generally speaking, given the increasing importance of private labels and premium segments, the necessity of an independent and transparent grading mechanism at the cooperative- or farm-level should be taken into account by major stakeholders concerned with the liberalization process in Mali to prevent any further drop in the quality. Of course, this element should be associated with price differentiation at the primary purchase level to enhance the quality of West African cotton (see Larsen, 2002, and Poulton et al., 2004, for similar results in other African regions).

The second implication concerns the future of FT and particularly the evolution of the FLO system and its actors (the FLO-International foundation and its national affiliates, and the inde-

23. Source: Author's estimation made from CMDT's sales department information (keeping quantities sold unchanged).

24. For coffee, Renard (2005) underlines similar results in Latin American countries, whereas de Janvry et al. (2011) find that FT-coffee growers in Central America sell their production on FT markets when its quality is too low to get high prices on non-FT markets.

25. If truck drivers and gin workers adopt better practices for cotton provided by certified cooperatives, this could provide another explanation for quality improvements. That would not change the global picture (FT improves the quality of Malian cotton), but it would modify substantially the explanation and the implications derived. However, field observations do not support the alternative explanation as transport and ginning practices are the same for certified and conventional cotton. Moreover, if ginning practices were different for Fairtrade cotton, one would certainly observe different ginning ratio (seed cotton weight / lint weight), which is not the case (while the average ginning ratio in conventional cooperatives - $39 \%$ - is statically different from the one of FT cooperatives $-41 \%$ - the difference is very small). Similarly, if FT had led to differentiated transport practices for Fairtrade cotton, we should observe differences in the "cooperative-to-factory" weight ratio (cotton weight at the village / cotton weight at the factory entrance). Again this is not the case as the average ratio is 1.053 for conventional cotton and 0.999 for certified cotton (and the difference is not statistically different from zero). Lastly, one could think that the impact of Fairtrade is mainly due to better agricultural advice provided to certified cooperatives. Indeed, CMDT's agents indicated that they have much more work in certified cooperatives. However, this effect is still attributable to a change in producers' behavior as extension agents would not spend so much time explaining standards if producers did not listen to them. 
pendent third-party certification body FLO-Cert). Given that there is restriction on FT demand, respective roles of the FLO's system operators could be redesigned to be made more efficient in helping small producers gain shares in other high value-added markets (see also Ruben \& Zuniga, 2011). FLO-International, for example, could provide aid-for-trade services to support small producers in developing countries to design, produce, and market high-quality products. Indeed, FLO-International and its national affiliates such as Max Havelaar France have developed support and marketing competencies that could help many producers in developing countries. FLO-Cert, on the other hand, could diversify its services and act as an independent third-party in other sectors than only $\mathrm{FT}^{26} \mathrm{In}$ a nutshell, $\mathrm{FT}$ actors and their competencies should be included in contract farming initiatives for agricultural development to make them more efficient in supporting small-scale farmers' production upgrading and marketing.

\section{References}

- Angrist, J. D., \& Pischke, J.-S. (2009). Mostly Harmless Econometrics: An Empiricist's Companion. Princeton, NJ: Princeton University Press.

- Arnould, E. J., Plastina, A., \& Ball, D. (2009). Does Fair Trade deliver on its core value proposition? Effects on income, educational attainment, and health in three countries. Journal of Public Policy and Marketing, 28 (2), 186-201.

- Arellano, M., \& Bover, O. (1995). Another Look at the Instrumental Variable Estimation of Error-Components Models. Journal of Econometrics, 68 (1), 29-51.

- Ashenfelter, O. (1978). Estimating the Effect of Training Programs on Earnings. Review of Economics and Statistics, 60 (1), 47-57.

- Ashenfelter, O., \& Card, D. (1985). Using the Longitudinal Structure of Earnings to Estimate the Effect of Training Programs. Review of Economics and Statistics, 67 (4), 648-660.

- Bacon, C. M. (2005). Confronting the coffee crisis: Can Fair Trade, organic, and specialty coffees reduce small-scale farmer vulnerability in northern Nicaragua? World Development, 33 (3), 497-511.
- Bacon, C. M. (2010). Who decides what is fair in fair trade? The agri-environmental governance of standards, access, and price. Journal of Peasant Studies, 37 (1), 111-147.

- Badiane, O., Ghura, D., Goreux L., \& Masson P. (2002). Cotton Sector Strategies in West and Central Africa. World Bank policy research working paper $n^{\circ} 2867$, Washington, D.C: World Bank.

- Balineau, G. (2011). Le renforcement des organisations de producteurs de coton au Mali: enjeux, impact et leçons du commerce équitable pour la privatisation de la filière. Canadian Journal of Development Studies, 32 (3), 297-312.

- Balineau, G., \& Dufeu, I. (2010). Are Fair Trade goods credence goods? A new proposal, with French illustrations. Journal of Business Ethics, 92 (1), 331-345.

- Barham, B. L., Callenes, M., Gitter, S., Lewis, J., \& Weber, J. (2011). Fair Trade/ organic coffee, rural livelihoods, and the 'Agrarian Question': southern Mexican coffee families in transition. World Development, 39 (1), 134-145.

- Bassett, T. J. (2010). Slim pickings: Fairtrade cotton in West Africa. Geoforum, 41 (1), 44-55.

\footnotetext{
26. FLO-Cert has actually begun such a diversification as the company now proposes carbon footprint assessment according to the GHG protocol (GreenHouse Gas protocol).
} 
- Becchetti, L., \& Costantino, M. (2008). The effects of fair trade on affiliated producers: An impact analysis on Kenyan farmers. World Development, 36 (5), 823-842.

- Becchetti, L., Costantino, M., \& Portale, E. (2008). Human capital, externalities and tourism: three unexplored sides of the impact of FT affiliation on primary producers. Working Paper $n^{\circ} 262$, Rome: CEIS, Tor Vergata University.

- Becchetti, L., \& Rosati, F. C. (2007). Global social preferences and the demand for socially responsible products: Empirical evidence from a pilot study on fair trade consumers. World Economy, 30 (5), 807-836.

- Beuchelt, T. D., \& Zeller, M. (2011). Profits and poverty: Certification's troubled link for Nicaragua's organic and fairtrade coffee producers. Ecological Economics, 70 (7), 13161324.

- Bingen, J. (2006). Cotton in West Africa: A Question of Quality. In J. Bingen, \& L. Busch (Eds.), Agricultural Standards: The Shape of the Global Food and Fiber System (pp. 219242). Dordrecht, The Netherlands: Springer.

- Blundell, R., \& Bond, S. (1998). Initial conditions and moment restrictions in dynamic panel data models. Journal of Econometrics, 87 (1), 115-143.

- Bolwig, S., Gibbon, P., \& Jones, S. (2009). The Economics of Smallholder Organic Contract Farming in Tropical Africa. World Development, 37 (6), 1094-1104.

- Cameron, A. C. \& Trivedi, P.K. (2005). Microeconometrics: methods and applications. Cambridge M.A.: Cambridge University Press.

- Chay, K. Y., McEwan, P. J., \& Urquiola, M. (2005). The central role of noise in evaluating interventions that use test scores to rank schools. American Economic Review, 95 (4), 1237-1258.

- CMDT (Compagnie Malienne pour le Développement des Textiles) (2004). Note technique sur le commerce équitable du coton. Bamako, Mali: CMDT.
- De Janvry, A., McIntosh, C., \& Sadoulet, E. (2010). Fair Trade and free entry: Generating benefits in a disequilibrium market. Working paper.

- Duflo, E. (2002). Empirical Methods. mimeo, MIT.

- Fridell, M., Hudson, I., \& Hudson, M. (2008). With friends like these: The corporate response to fair trade coffee. Review of Radical Political Economics, 40 (1), 8-34.

- Galiani, S., Gertler, P., \& Schargrodsky, E. (2005). Water for life: The impact of the privatization of water services on child mortality. Journal of Political Economy, 113 (1), 83-120.

- Giraudy, F. (2005). Comment insérer harmonieusement le commerce équitable dans les filières cotonnières d'Afrique francophone? (Unpublished), DAGRIS, Paris.

- Goldhaber, D., \& Anthony, E. (2007). Can teacher quality be effectively assessed? National board certification as a signal of effective teaching. Review of Economics and Statistics, 89 (1), 134-150.

- Hayes, M. G. (2008). Fighting the Tide: Alternative Trade Organizations in the Era of Global Free Trade - A Comment. World Development, 36 (12), 2953-2961.

- Head, K., \& Ries, J. (2010). Do trade missions increase trade? Canadian Journal of Economics, 43 (3), 764-775.

- Heckman, J. J., \& Smith, J. A. (1999). The pre-programme earnings dip and the determinants of participation in a social programme. Implications for simple programme evaluation strategies. Economic Journal, 109 (457), 313-348.

- ITMF (International Textile Manufacturers Federation) (2008). Cotton Contamination Surveys: $1999-2001-2003-2005-2007$. Zürich (Switzerland): ITMF.

- Jaffee, D. (2008). Better, But Not Great: The Social and Environmental Benefits and Limitations of Fair Trade for Indigenous Coffee Producers in Oaxaca, Mexico. In R. Ruben (Ed.), The Impact of Fair Trade (pp. 195-222). Wagenigen, Netherlands: Wagenigen Academic Publishers. 
- Janssens, W. (2006). Measuring externalities in program evaluation. Discussion Paper, The Tinbergen Institute, Amsterdam (Netherlands).

- Kaplinsky, R. (2006). Revisiting the Revisited Terms of Trade: Will China Make a Difference? World Development, 34 (6), 981-995.

- Larsen, M. N. (2002). Is oligopoly a condition of successful privatization? The case of cotton in Zimbabwe. Journal of Agrarian Change, 2 (2), 185-205.

- Larsen, M. N. (2003). Quality StandardSetting in the Global Cotton Chain and Cotton Sector Reforms in Sub-Saharan Africa. Working Paper 03.7, Institute for International Studies, Copenhagen (Denmark).

- Leclair, M. S. (2002). Fighting the tide: Alternative trade organizations in the era of global free trade. World Development, 30 (6), 949-958.

- Leclair, M. S. (2008). Fighting the Tide: Alternative Trade Organizations in the Era of Global Free Trade - A Reply. World Development, 36 (12), 2962-2965.

- Mendoza, R., \& Bastiaensen, J. (2003). Fair trade and the coffee crisis in the Nicaraguan Segovias. Small Enterprise Development, 14 (2), 36-46.

- Miguel, E., \& Kremer, M. (2004). Worms: Identifying impacts on education and health in the presence of treatment externalities. Econometrica, 72 (1), 159-217.

- Poulton, C., Gibbon, P., HanyaniMlambo, B., Kydd, J., Maro, W., Larsen, M.N., ... Zulu, B. (2004). Competition and Coordination in Liberalized African Cotton Market Systems. World Development, 32 (3), 519-536.

- Ravallion, M. (2005). Evaluating AntiPoverty Programs. World Bank policy research working paper $n^{\circ} 3625$, Washington D.C.: World Bank.

- Raynolds, L.T. (2009). Mainstreaming Fair Trade Coffee: From Partnership to Traceability. World Development, 37 (6), 10831093.
- Renard, M.-C. (2005). Quality certification, regulation and power in fair trade. Journal of Rural Studies, 21 (4), 419-431.

- Ronchi, L. (2006). Fairtrade and market failures in agricultural commodity markets. World Bank policy research working paper n4011, Washington D.C.: World Bank.

- Ruben, R. \& Forth, R. The Impact of Fair Trade Certification for Coffee Farmers in Peru. World Development (2011), doi:10.1016/j.worlddev.2011.07.030

- Ruben, R., \& Zuniga, G. (2011). How standards compete: comparative impact of coffee certification schemes in Northern Nicaragua. Supply Chain Management International Journal, 16 (2), 98-109.

- Torero, M., \& Viceisza, A. (2011). Potential Collusion and Trust Evidence from a Field Experiment in Vietnam. IFPRI Discussion Paper $n^{\circ} 01100$. Washington, D.C.: IFPRI.

- Tschirley, D., Poulton, C., \& Labaste, P. (2009). Organization and Performance of Cotton Sectors in Africa. Learning from Reform Experience. Washington, D.C.: World Bank

- Valkila, J. (2009). Fair Trade organic coffee production in Nicaragua - Sustainable development or a poverty trap? Ecological Economics, 68 (12), 3018-3025.

- Weber, J. G. (2011). How much more do growers receive for Fair Trade-organic coffee? Food Policy, 36 (5), 678-685.

- Wodon, Q., Briand, V., Labaste, P., Nouvé, K., \& Sangho, Y. (2006). Cotton and Poverty in Mali. Draft World Bank working paper, Washington, D.C.: World Bank.

- Wooldridge, J. M. (2002). Econometric Analysis of Cross-Section and Panel Data. Cambridge M.A.: MIT Press.

- World Bank (2007). World Development Report 2008: Agriculture for Development. Washington, D.C.: World Bank.

- Yanchus, D., \& de Vanssay, X. (2003). The myth of fair prices: A graphical analysis. Journal of Economic Education, 34 (3), 235240.

- Zehner, D.C. (2002). An economic assessment of 'fair trade'in coffee, Chazen Web Journal of International Business, (Fall), 1-24. 


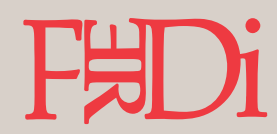

Créée en 2003, la Fondation pour les études et recherches sur le développement international vise à favoriser la compréhension du développement économique international et des politiques qui l'influencent.

\section{$C$ Contact}

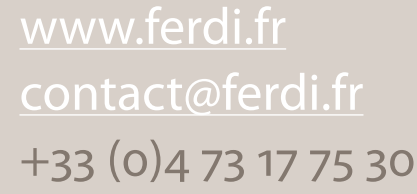

